\title{
Kolkisin forebygger residiv av perikarditt
}

\section{Kolkisin er effektivt som behandling og sekundærprofylakse ved perikarditt, viser randomisert studie.}

Nye episoder med perikarditt forekommer ofte etter akutt perikarditt. Kolkisin har vist lovende resultater i åpne studier.

120 pasienter ved fire italienske sykehus med første residiv etter akutt perikarditt ble

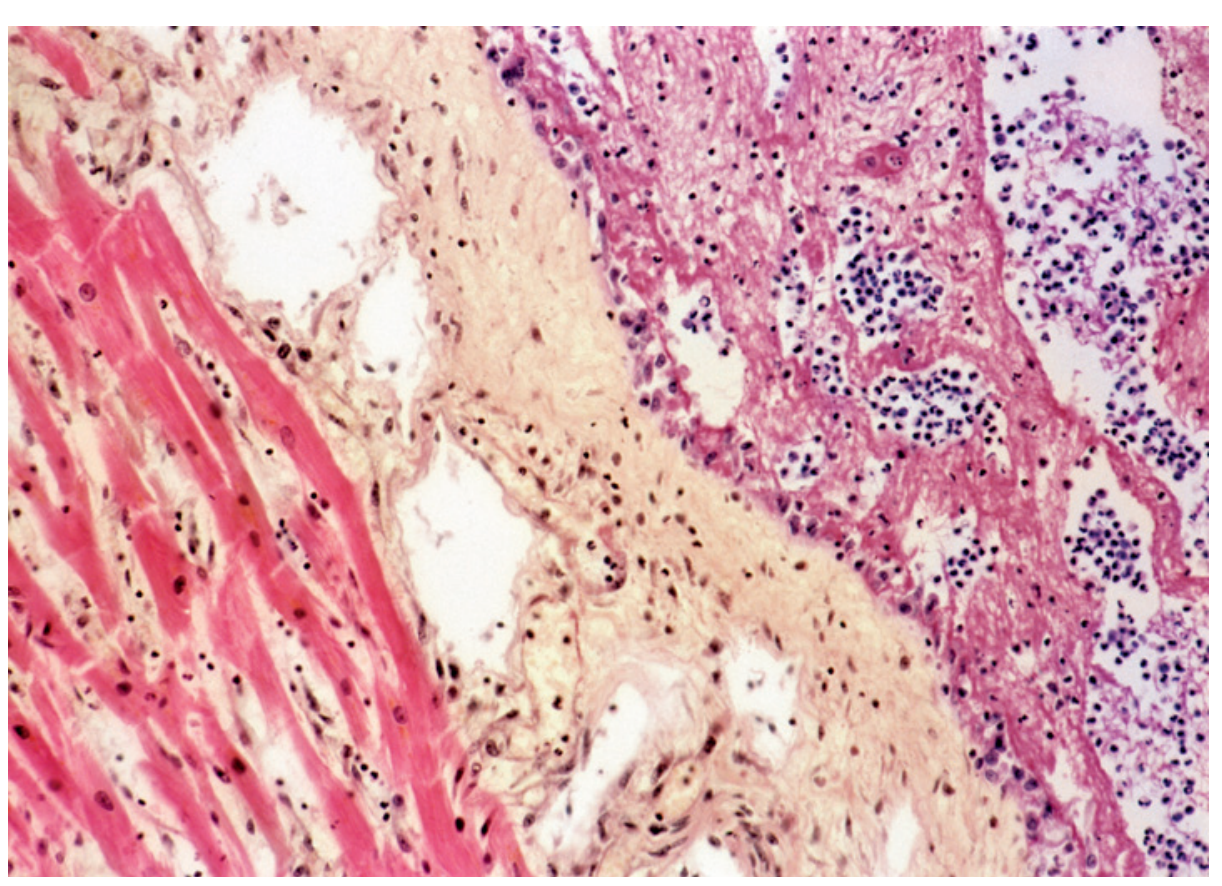

Illustrasjonsfoto SCANPIX/Sciencephoto tillegg til konvensjonell behandling med antiinflammatoriske legemidler (1). Startdosen var 1-2 mg første dag, deretter $0,5-1,0 \mathrm{mg}$ per dag i seks måneder. randomisert til å få kolkisin eller placebo i

\section{Petter Gjersvik}

petjense@online.no

Tidsskriftet

\section{Litteratur}

1. Imazio M, Brucato A Cemin R et al. Colchicine for recurrent pericarditis (CORP). A randomized trial. Ann Intern Med 2011; 155: 409-14.

\section{Bør urinprøver inngå i helseundersøkelser av friske?}

\section{Mikroskopisk hematuri uten \\ tilleggssymptomer kan være et tidlig tegn på nyresykdom.}

En undersøkelse fra Israel viser at asymptomatisk hematuri gir økt risiko for nyresvikt mange år senere (1). Funnene baserer seg på data fra mer enn en million rekrutter som var til sesjon i perioden 1975-97. Persisterende asymptomatisk hematuri ble definert som mikroskopisk bekreftet hematuri ved minst tre tidspunkter, samtidig som supplerende undersøkelser var negative. Bare $0,3 \%$ av deltakerne oppfylte disse kriteriene.

Ved å koble opplysningene til et nasjonalt helseregister for dialyse- eller transplantasjonstrengende pasienter, fant man at sannsynligheten for nyresvikt i løpet av 22 år hos disse var $0,7 \%$, eller nesten 20 ganger så høy som hos dem som ikke hadde hatt hematuri. I en ledsagende kommentar anbefales det at man igjen innfører urinprøver som en del av helseundersøkelser av unge voksne (2).

- Studien viser at isolert mikrohematuri kan være et tegn på begynnende nyresykdom, sier overlege Anders Hartmann ved Oslo universitetssykehus. - Men forekomsten av alvorlig sykdom var likevel lav. Dessuten fikk de fleste som ble syke kronisk glomerulonefritt, en tilstand som bare unntaksvis kan forebygges eller behandles med spesifikke midler.

I dag mener vi den beste måten å screene på er å måle proteinuri og estimere nyrefunksjon ut fra serum-kreatininnivå. Studien viser at man også bør vurdere isolert mikrohematuri som risikofaktor for senere nyre- svikt. Men dataene alene gir ikke tilstrekkelig grunnlag for å anbefale systematiske masseundersøkelser på befolkningsnivå. Hvis man derimot tilfeldig avdekker vedvarende mikrohematuri hos unge mennesker, er det viktig å utelukke sykdommer i urinveiene. Deretter bør man følge opp pasienten med 1-2 års mellomrom, sier Hartmann.

\section{Ragnhild Ørstavik}

ragnhild.orstavik@fhi.no

Tidsskriftet

Litteratur
1. Vivante A, Afek A, Frenkel-Nir Y. Persistent asymptomatic isolated microscopic hematuria in Israeli adolescents and young adults and risk for end-stage renal disease. JAMA 2011; 306: 729-36.

2. Brown R. Has the time come to include urine dipstick testing in screening asymptomatic young adults? JAMA 2011; 306: 764-5. 